NBER WORKING PAPER SERIES

\title{
WHAT DOES FUTURES MARKET INTEREST TELL US ABOUT THE MACROECONOMY AND ASSET PRICES?
}

\author{
Harrison Hong \\ Motohiro Yogo \\ Working Paper 16712 \\ http://www.nber.org/papers/w16712 \\ NATIONAL BUREAU OF ECONOMIC RESEARCH \\ 1050 Massachusetts Avenue \\ Cambridge, MA 02138 \\ January 2011
}

This paper subsumes our earlier work that focused on the commodity market. For comments and discussions, we thank Erkko Etula, Hong Liu, Nikolai Roussanov, Allan Timmermann, Robert Vigfusson, and seminar participants at Boston College, Carnegie Mellon University, Centre de Recherche en Economie et Statistique, Columbia University, Dartmouth College, Federal Reserve Bank of Chicago, Fordham University, Imperial College London, International Monetary Fund, London School of Economics, Northwestern University, Ohio State University, PanAgora Asset Management, SAC Capital Advisors, Stockholm Institute for Financial Research, Stockholm School of Economics, University of California at Los Angeles, University of California at San Diego, University of Minnesota, University of Pennsylvania, University of Rochester, University of Southern California, University of Texas at Austin, University of Tokyo, Washington University in St. Louis, the 2008 Economic Research Initiatives at Duke Conference on Identification Issues in Economics, the 2010 Annual Meeting of the American Finance Association, the 2010 National Bureau of Economic Research Summer Institute Working Group on Forecasting and Empirical Methods in Macroeconomics and Finance, and the 2011 Commodity Futures Trading Commission Conference on Commodity Markets. We thank Hyun Soo Choi, Hui Fang, Jennifer Kwok, Yupeng Liu, James Luo, Thien Nguyen, and Elizabeth So for research assistance. Harrison Hong acknowledges support from the National Science Foundation (grant SES-0850404). Motohiro Yogo acknowledges support from the Rodney L. White Center for Financial Research at the University of Pennsylvania. The views expressed herein are ours and not necessarily those of the Federal Reserve Bank of Minneapolis, the Federal Reserve System, or the National Bureau of Economic Research.

NBER working papers are circulated for discussion and comment purposes. They have not been peerreviewed or been subject to the review by the NBER Board of Directors that accompanies official NBER publications.

(C) 2011 by Harrison Hong and Motohiro Yogo. All rights reserved. Short sections of text, not to exceed two paragraphs, may be quoted without explicit permission provided that full credit, including $(\subset$ notice, is given to the source. 
What Does Futures Market Interest Tell Us about the Macroeconomy and Asset Prices?

Harrison Hong and Motohiro Yogo

NBER Working Paper No. 16712

January 2011, Revised June 2012

JEL No. E31,E37,F31,G12,G13

\begin{abstract}
$\underline{\text { ABSTRACT }}$
Economists have traditionally viewed futures prices as fully informative about future economic activity and asset prices. We argue that open interest could be more informative than futures prices in the presence of hedging demand and limited risk absorption capacity in futures markets. We find that movements in open interest are highly pro-cyclical, correlated with both macroeconomic activity and movements in asset prices. Movements in commodity market interest predict commodity returns, bond returns, and movements in the short rate even after controlling for other known predictors. To a lesser degree, movements in open interest predict returns in currency, bond, and stock markets.
\end{abstract}

\author{
Harrison Hong \\ Department of Economics \\ Princeton University \\ 26 Prospect Avenue \\ Princeton, NJ 08540 \\ and NBER \\ hhong@princeton.edu \\ Motohiro Yogo \\ Federal Reserve Bank of Minneapolis \\ Research Department \\ 90 Hennepin Avenue \\ Minneapolis, MN 55401-1804 \\ yogo@minneapolisfed.org
}




\section{Introduction}

Economists have traditionally viewed futures prices as fully informative about future economic activity and asset prices and have remained silent on the role of open interest, or the amount of futures contracts outstanding (Samuelson, 1965; Grossman, 1977). The theory of backwardation implies that the risk premium depends only on the net supply-demand imbalance among hedgers in the futures market, not on the gross amount of futures contracts outstanding (Keynes, 1923; Hicks, 1939). The range of empirical work that uses futures market data reflects these traditional theories. Macroeconomists use commodity futures and spot prices to forecast inflation. International economists use the forward discount, or the ratio of futures to spot price in the currency market, to forecast movements in exchange rates. Financial economists use the yield spread to forecast bond and stock returns.

In this paper, we show that open interest contains information about future economic activity and asset prices that is not fully revealed by futures prices or net supply-demand imbalances among hedgers in futures markets. Our point of departure from these traditional theories is the observation that gross (as opposed to net) hedging demand, by either producers or consumers of commodities, tends to be pro-cyclical. For example, oil producers that anticipate higher demand could go short oil futures, while utilities that anticipate higher demand from manufacturing firms could go long oil futures. Importers that anticipate higher US demand could go short currency futures, while exporters that anticipate higher US demand could go long currency futures. Financial firms and insurance companies that anticipate expansion of their balance sheets could enter bond and stock market futures to hedge interest rate and equity risk. In all of these examples, anticipation of higher economic activity leads to higher hedging demand, which drives up open interest.

In a simple model, we show that open interest is a more reliable signal of higher economic activity and, consequently, future movements in asset prices than futures prices. The key assumption is limited risk absorption capacity in the futures market. If there is excess hedging demand from producers that want to be short futures, the futures price will fall 
due to limited arbitrage by speculators. Conversely, if there is excess hedging demand from consumers that want to be long futures, the futures price will rise due to limited arbitrage by speculators. Because the futures price can either fall or rise in response to anticipation of higher economic activity, the futures price is a less reliable signal of future economic activity and asset prices than open interest.

We show a number of new facts that are consistent with this view of futures markets. First, movements in open interest are highly correlated with movements in both futures and spot prices in commodity, currency, bond, and stock markets. In each of these markets, movements in open interest are positively correlated with the Chicago Fed National Activity Index, which is a weighted average of 85 monthly indicators of US economic activity. Periods of high US economic activity tend to coincide with high commodity returns, appreciation of foreign currencies relative to the US dollar, low bond returns, and high stock returns. The fact that movements in open interest are pro-cyclical is surprising because open interest does not necessarily signal the direction of hedging demand.

Second, movements in open interest predict returns. Our main evidence is from the commodity market, which is relatively ideal for testing our hypothesis because hedging demand and limited risk absorption capacity tend to be more important in this market. Moreover, our sample for the commodity market starts in 1966, which is much earlier than 1984 for the other markets. We find that a standard deviation increase in commodity market interest increases expected commodity returns by $0.73 \%$ per month, which is both economically large and statistically significant. Commodity market interest remains a powerful predictor even after controlling for a number of other predictors including the short rate, the yield spread, the Chicago Fed National Activity Index, commodity basis (i.e., the ratio of futures to spot price in the commodity market), commodity market imbalance (i.e., excess hedging demand from hedgers), and past commodity returns. Interestingly, a high yield spread or a high Chicago Fed National Activity Index predicts low commodity returns, implying that expected commodity returns are pro-cyclical. 
We find qualitatively similar, but statistically weaker, evidence for predictability of returns in currency, bond, and stock markets. We find that rising currency market interest, which signals higher US economic activity and rising inflation expectations, predicts appreciation of a portfolio of foreign currencies relative to the US dollar. Notably, currency market interest has more forecasting power than the forward discount, which is a leading predictor of exchange rates in international finance. Similarly, rising bond market interest, which signals higher economic activity and rising inflation expectations, predicts low bond returns. Finally, rising stock market interest predicts high stock returns, although the statistical evidence is the weakest for this market.

Third, we find that rising commodity market interest predicts low bond returns and a rising short rate. A standard deviation increase in commodity market interest decreases expected bond returns by $0.32 \%$ per month, which is highly statistically significant. This finding supports our hypothesis that commodity market interest reflects hedging in response to news about higher economic activity. Anticipation of higher economic activity, which is bad news for the bond market, predicts low bond returns and rising inflation expectations.

Our preferred interpretation of the evidence is that open interest contains information about future economic activity and inflation expectations that is not immediately impounded in asset prices. An alternative interpretation, that open interest captures time-varying risk premium, is less likely because the relation between movements in open interest and asset prices implies momentum instead of mean reversion. That is, movements in open interest are positively correlated with both contemporaneous and future returns, which imply momentum generated by underreaction to news captured by open interest.

The remainder of the paper proceeds as follows. Section 2 presents a model in which cyclical variation in open interest predicts returns. Section 3 describes the futures market data and the construction of the key variables for empirical analysis. Section 4 presents evidence that movements in open interest are highly pro-cyclical, correlated with both macroeconomic activity and movements in asset prices. Section 5 presents evidence that movements 
in open interest predict returns even after controlling for other known predictors. Section 6 concludes.

\section{A model in which open interest predicts returns}

We develop a simple model of the futures market that explains why open interest can be a better predictor of returns than futures prices or the direction of hedging demand. For

expositional purposes, the underlying asset in our model is a commodity. The economics of the model would be the same if the underlying asset were a currency, a bond, or a stock as long as gross hedging demand rises with economic activity.

Our model is based on two plausible assumptions. First, information diffuses gradually in financial markets, which causes asset prices to initially underreact to news. This assumption has been used successfully in a variety of contexts including macroeconomics (Mankiw and Reis, 2002), international finance (Gourinchas and Tornell, 2004), and financial economics (Hong and Stein, 1999). Hong and Stein (2007) survey a large literature that presents evidence for the underreaction of asset prices to news. Second, supply shocks move asset prices due to financial market frictions that limit arbitrage (De Long, Shleifer, Summers, and Waldmann, 1990). Compelling evidence for downward-sloping demand exists in a variety of financial markets, even highly liquid ones such as bond and stock markets (see Shleifer, 1986, for early evidence on stocks).

\subsection{Economic environment}

There are three periods, indexed as $t=0,1,2$. The riskless interest rate is constant and normalized to zero. There is a spot market for a commodity in period 2, and there is a futures contract on the same commodity that is traded in periods 0 and 1 . Let $S_{2}$ denote the spot price for the commodity in period 2, which we assume is exogenous and stochastic. In period 1, the economy can be in one of two states, "high" or "low". In the high state, 
the spot price in period 2 is distributed as $S_{2} \sim \mathbf{N}\left(S^{H}, \sigma^{2}\right)$. In the low state, the spot price in period 2 is distributed as $S_{2} \sim \mathbf{N}\left(S^{L}, \sigma^{2}\right)$. There is relatively high demand for the commodity in the high state so that $S^{H}>S^{L}{ }^{1}$ In period 0 , the probability that the economy is in the high state in period 1 is $\pi=0.5$. Note that

$$
\mathbf{E}_{0}\left[S_{2}\right]=\pi S^{H}+(1-\pi) S^{L}=\bar{S}
$$

and

$$
\operatorname{Var}_{0}\left(S_{2}\right)=\sigma^{2}+\pi S^{H 2}+(1-\pi) S^{L 2}-\bar{S}^{2}
$$

In period 1 , there are producers that commit to production of the commodity for delivery in period 2. Alternatively, there are producers that commit to use the commodity as an input for production in period 2. The producers know the state of the economy in period 1 (i.e., whether it is high or low), but they still face uncertainty about the spot price (captured by $\sigma^{2}$ ). Let $Y^{H}$ denote the quantity of the commodity that the producers commit to selling (or buying) in the high state. Let $Y^{L}$ denote the quantity of the commodity that the producers commit to selling (or buying) in the low state. In each state, $Y>0$ if the commodity is an output, and $Y<0$ if the commodity is an input for the producers. We make a natural assumption that there is relatively more demand for the commodity in the high state so that $\left|Y^{H}\right|>\left|Y^{L}\right|$. We normalize $Y^{L}=0$ to simplify notation.

The producers are infinitely risk-averse and would like to hedge all uncertainty about the spot price. They can do so by entering the futures market in period 1. Let $F_{t}$ denote the futures price in period $t$ on a contract that matures in period 2. The producers choose the optimal futures position $D_{1}^{P}$ to minimize the variance of their total profit from production

\footnotetext{
${ }^{1}$ To tailor our model to bond markets, we must reverse this inequality because high economic activity is bad news for bonds. All the derivations in this subsection then follow through, resulting in a key prediction that a high growth rate of open interest signals a low expected bond return.
} 
and hedging activity:

$$
\min _{D_{1}^{P}} \operatorname{Var}_{1}\left(S_{2} Y+\left(S_{2}-F_{1}\right) D_{1}^{P}\right) .
$$

The producers can perfectly hedge all uncertainty by choosing $D_{1}^{P}=-Y$. The producers are short futures if the commodity is an output, and they are long futures if the commodity is an input. The producers are active in the futures market only in the high state because $D_{1}^{P}=-Y^{L}=0$ in the low state. Otherwise, the producers do not participate in the futures market.

In addition to the producers, two other groups of investors are in the futures market. The first group consists of informed one-period investors, who have mass $\lambda \in(0,1)$ in the population of investors. They have the usual mean-variance objective function with riskaversion parameter $\gamma$. These investors are informed in the sense that they are fully aware of the probability distribution for $S_{2}$ in each period. In particular, they know the state of the economy in period 1. The informed investors choose the optimal futures position $D_{t}^{I}$ in periods $t=0,1$ to maximize their objective function. The optimal futures position is given by the usual mean-variance demand function:

$$
D_{t}^{I}=\frac{\mathbf{E}_{t}\left[F_{t+1}-F_{t}\right]}{\gamma \operatorname{Var}_{t}\left(F_{t+1}-F_{t}\right)} .
$$

The second group consists of uninformed one-period investors, who have mass $1-\lambda$ in the population of investors. They also have a mean-variance objective function with risk-aversion parameter $\gamma$. The key modeling assumption is that these uninformed investors underreact to news about the state of the economy. Specifically, they are unaware of the state of the economy in period 1 , so their subjective distribution of $S_{2}$ in period 1 is the same as their prior about $S_{2}$ in period 0 . The uninformed investors choose the optimal futures position $D_{t}^{U}$ in periods $t=0,1$ to maximize their objective function. The optimal futures position is 
given by the mean-variance demand function:

$$
D_{t}^{U}=\frac{\bar{S}-F_{t}}{\gamma \operatorname{Var}_{0}\left(S_{2}\right)} .
$$

\subsection{Equilibrium futures prices}

We now solve for the equilibrium futures price in period 1. The market-clearing condition in period 1 is

$$
\lambda D_{1}^{I}+(1-\lambda) D_{1}^{U}+D_{1}^{P}=0
$$

Substituting the demand functions, the futures price in the high state is

$$
F_{1}^{H}=\omega_{1} S^{H}+\left(1-\omega_{1}\right) \bar{S}-\frac{\omega_{1} \gamma \sigma^{2} Y^{H}}{\lambda}
$$

where

$$
\omega_{1}=\frac{\lambda \operatorname{Var}_{0}\left(S_{2}\right)}{\lambda \operatorname{Var}_{0}\left(S_{2}\right)+(1-\lambda) \sigma^{2}} .
$$

The futures price in the low state is

$$
F_{1}^{L}=\omega_{1} S^{L}+\left(1-\omega_{1}\right) \bar{S}
$$

We now work backward to solve for the equilibrium futures price in period 0 . The market-clearing condition in period 0 is

$$
\lambda D_{0}^{I}+(1-\lambda) D_{0}^{U}=0 .
$$


Substituting the demand functions, the futures price is

$$
F_{0}=\omega_{0}\left(\bar{S}-\frac{\pi \omega_{1} \gamma \sigma^{2} Y^{H}}{\lambda}\right)+\left(1-\omega_{0}\right) \bar{S}
$$

where

$$
\omega_{0}=\frac{\lambda \operatorname{Var}_{0}\left(S_{2}\right)}{\lambda \operatorname{Var}_{0}\left(S_{2}\right)+(1-\lambda) \operatorname{Var}_{0}\left(F_{1}\right)} .
$$

Open interest, or the quantity of futures contracts outstanding, is

$$
O_{0}=\lambda\left|D_{0}^{I}\right|=(1-\lambda)\left|D_{0}^{U}\right|=\pi \omega_{0}\left(1-\omega_{1}\right)\left|Y^{H}\right| .
$$

We now make two key observations about the model. The first observation is that the futures price in the high state is lower than that in the low state if hedging demand is sufficiently high. More formally, $F_{1}^{H}<F_{1}^{L}$ if

$$
Y^{H}>\frac{\lambda\left(S^{H}-S^{L}\right)}{\gamma \sigma^{2}} .
$$

The intuition for this result is straightforward. In the high state, good news about the economy leads to a high futures price in the absence of hedging by the producers. In the presence of hedging demand, however, the producers put downward pressure on the futures price when $Y^{H}>0$. Because investors have limited risk-bearing capacity (captured by $\gamma \sigma^{2}$ ), hedging demand can more than offset the impact of good news, leading to a low futures price.

The second observation is that open interest in the high state is always higher than that in the low state because of hedging by the producers. In the high state, the informed investors are the only ones to be long futures if $Y^{H}>0$, while both the informed investors 
and the producers are long futures if $Y^{H}<0$. Therefore, open interest in the high state is

$$
O_{1}^{H}= \begin{cases}\lambda D_{1}^{I}=\frac{\lambda\left(1-\omega_{1}\right)\left(S^{H}-\bar{S}\right)}{\gamma \sigma^{2}}+\omega_{1} Y^{H} & \text { if } Y^{H}>0 \\ \lambda D_{1}^{I}+D_{1}^{P}=\frac{\lambda\left(1-\omega_{1}\right)\left(S^{H}-\bar{S}\right)}{\gamma \sigma^{2}}-\left(1-\omega_{1}\right) Y^{H} & \text { if } Y^{H}<0\end{cases}
$$

In the low state, the uninformed investors are the only ones to be long futures. Therefore, open interest in the low state is

$$
O_{1}^{L}=(1-\lambda) D_{1}^{U}=\frac{\lambda\left(1-\omega_{1}\right)\left(\bar{S}-S^{L}\right)}{\gamma \sigma^{2}}
$$

Note that $O_{1}^{H}>O_{1}^{L}$ because $S^{H}-\bar{S}=\bar{S}-S^{L}$ (implied by $\pi=0.5$ ). Importantly, this is true regardless of the direction of hedging demand (i.e., whether $Y^{H}>0$ or $Y^{H}<0$ ).

Define the return on futures between periods 0 and 1 as $R_{1}=F_{1}-F_{0}$. Similarly, define the return on futures between periods 1 and 2 as $R_{2}=S_{2}-F_{1}$. The expected return on futures between periods 1 and 2 is

$$
\mathbf{E}_{1}\left[R_{2}\right]=\left\{\begin{array}{ll}
\left(1-\omega_{1}\right)\left(S^{H}-\bar{S}\right)+\frac{\omega_{1} \gamma \sigma^{2} Y^{H}}{\lambda} & \text { in the high state } \\
-\left(1-\omega_{1}\right)\left(\bar{S}-S^{L}\right) & \text { in the low state }
\end{array} .\right.
$$

We assume that the parameters of the model satisfy the restriction

$$
Y^{H}>\frac{-\lambda\left(1-\omega_{1}\right)\left(S^{H}-S^{L}\right)}{\omega_{1} \gamma \sigma^{2}}
$$

which guarantees that the expected return in the high state is higher than that in the low state. This restriction essentially rules out the extreme case in which hedging demand is so negative and large as to completely undo the underreaction of the futures price to news in period 1 . We are now ready to state our main result.

Proposition 1. If $Y^{H}<\lambda\left(S^{H}-S^{L}\right) /\left(\gamma \sigma^{2}\right)$, a high return $R_{1}$ signals a high expected return $\mathbf{E}_{1}\left[R_{2}\right]$. Otherwise, a high return signals a low expected return. A high growth rate of open 
interest $O_{1} / O_{0}$ always signals a high expected return $\mathbf{E}_{1}\left[R_{2}\right]$, regardless of the direction of hedging demand (i.e., whether $Y^{H}>0$ or $Y^{H}<0$ ).

When hedging demand is sufficiently low or negative, a high return signals good news about the economy. Therefore, we would observe positive serial correlation in returns due to underreaction by the uninformed investors. When hedging demand is sufficiently high, however, a high return does not signal good news about the economy. Consequently, past returns are not a reliable predictor of future returns because the sign of the serial correlation depends on the importance of hedging demand. In contrast, a high growth rate of open interest unambiguously signals good news about the economy and, therefore, a high expected return.

The mechanism that generates predictability of returns in our model is distinct from that in the theory of backwardation. In the theory of backwardation, predictability arises from variation in the risk premium that speculators earn due to excess hedging demand in the futures market. Hence, this theory implies that the direction of hedging demand predicts returns. In our model, predictability arises from the underreaction of asset prices to news. Our model implies that movements in open interest predict returns, regardless of the direction of hedging demand.

\section{Futures market data and variable definitions}

\subsection{Futures market data}

Our data on futures and spot prices in commodity, currency, bond, and stock markets are from the Commodity Research Bureau. This database conveniently contains a comprehensive record of daily futures and spot prices for individual futures contracts since December $1964 .^{2}$

\footnotetext{
${ }^{2}$ This database contains only futures contracts that have survived until the present or that traded for an extended period in the past. Various futures contracts fail to survive because of the lack of investor interest, and they are subsequently not recorded in the database. Due to potential survivorship bias, one must be careful in interpreting the unconditional average return, which is not the focus of this paper.
} 
We also use data on open interest, or the quantity of futures contracts outstanding, as well as the long and short positions of commercial traders (i.e., hedgers) for each futures contract. Since January 1986, the data are available electronically from the Commodity Futures Trading Commission. Prior to that date, we hand-collected data from various volumes of the Commitments of Traders in Commodity Futures. Data for December 1964 through June 1972 are from the Commodity Exchange Authority (1964-1972). Data for July 1972 through December 1985 are from the Commodity Futures Trading Commission (1972-1985). During an 11-month period from January through November 1982, the Commodity Futures Trading Commission did not collect data due to budgetary reasons. Our analysis uses all available data and excludes the part of the sample affected by the 11-month gap.

\subsubsection{Commodity market}

We work with the broadest set of commodities for which both futures and spot prices are available. Table 1 lists the 30 commodities that are part of our analysis, together with the exchange in which they are traded and the date of the first recorded observation. ${ }^{3}$ We categorize the universe of commodities into four broad sectors. Agriculture consists of 14 commodities and tends to contain the oldest futures contracts. Energy consists of five commodities, among which heating oil is the oldest, available since November 1978. Crude oil is available only since March 1983. Livestock consists of five commodities, among which live cattle and pork bellies are available since December 1964. Metals consists of six commodities, among which copper and silver are available since December 1964.

Figure 1 shows the share of total dollar open interest that each sector represents. The figure shows that agriculture is the largest sector in the early part of the sample, while energy becomes the largest sector later in the sample. The relative size of the four sectors is much more balanced later in the sample. These stylized facts have two important

\footnotetext{
${ }^{3}$ A potential concern with this broad set of commodities is that not all futures contracts are equally liquid. In analysis that is not reported here, we confirm our main findings on a subset of 17 relatively liquid futures contracts that are in the Dow Jones-AIG Commodities Index.
} 
implications for our empirical analysis. First, we construct the commodity portfolio as an equally weighted portfolio of the four sectors, which ensures that the portfolio composition is consistent throughout the sample. Second, we have confirmed that our main findings are robust to splitting the sample into two halves in Hong and Yogo (2011).

\subsubsection{Currency, bond, and stock markets}

Our sample for currency, bond, and stock markets starts in December 1982 because the Commitments of Traders in Commodity Futures were not available between January and November 1982, and these futures markets were relatively small prior to that date. Table 2 lists the eight currency, 10 bond, and 14 stock futures that are part of our analysis, together with the exchange in which they are traded and the date of the first recorded observation.

The core set of currency futures for which we have data since December 1982 are the British pound, the Canadian dollar, the Deutsche mark, the Japanese yen, and the Swiss franc. The Australian dollar is available since January 1987; the New Zealand dollar since May 1997; and the euro since May 1998. Unlike the commodity market, trading in the currency market takes place predominantly in over-the-counter forward and swap markets. A potential concern arises in measuring currency market activity because open interest in the futures market is a small share of overall activity that includes the over-the-counter market. Unfortunately, data on open interest in the over-the-counter market are not available at the frequency or sample length necessary for our analysis. Despite this problem, the growth rate of open interest in the futures market should be a good proxy for the overall growth rate of the currency market as long as the futures and forward markets move (more or less) in proportion to one another. Insofar as open interest in the futures market is a noisy proxy for hedging and speculative activity in the currency market, this measurement problem would weaken the power of our statistical tests.

The universe of bond futures contains various fixed-income instruments that vary in maturity from 30-day federal funds to the 30-year Treasury bond. The oldest bond futures, 
available since December 1982, are those for the three-month Eurodollar, the three-month Treasury bill, the 10-year Treasury note, and the 30-year Treasury bond.

The universe of stock futures contains all major indices including the Dow Jones Industrial Index, the Major Market Index, the Nasdaq 100 Index, the NYSE Composite Index, the Russell 2000 Index, the Standard \& Poor's (S\&P) 400 and 500 indices, and the Value-Line Arithmetic Index. The oldest stock futures, available since December 1982, are those for the NYSE Composite Index and the S\&P 500 Index.

\subsection{Definition of returns}

We use returns on commodity futures to measure movements in commodity prices and returns on currency futures to measure movements in exchanges rates. We prefer commodity futures prices over spot prices for two reasons. First, commodity futures data are arguably higher quality with fewer missing observations because they are actual transaction prices. Second, the rate of return on commodity futures has a straightforward economic interpretation as an actual return on an investment strategy. That being said, we have confirmed our main findings using commodity and currency spot prices in Hong and Yogo (2011).

\subsubsection{Commodity market}

To construct the return on a portfolio of commodity futures, we first compute the return on a fully collateralized position for each futures contract as follows. Let $F_{i, t, T}$ be the futures price for commodity $i$ at the end of month $t$, for a futures contract that matures at the end of month $T$. Let $R_{f, t}$ be the monthly gross return on the one-month T-bill in month $t$, which is assumed to be the interest earned on collateral. The monthly gross return on a fully collateralized long position in futures contract $i$ with maturity $T-t$ is

$$
R_{i, t, T}=\frac{F_{i, t, T} R_{f, t}}{F_{i, t-1, T}} .
$$


That is, an investor can take a long position in month $t-1$ by posting $F_{i, t-1, T} / R_{f, t}$ dollars of collateral, then close out the position at $F_{i, t, T}$ in month $t$.

For each commodity, we compute its monthly gross return as an equally weighted average of returns across commodity futures with greater than one and less than 13 months to maturity. We exclude futures contracts with one month or less to maturity, which are typically illiquid because futures traders do not want to take physical delivery of the underlying. Similarly, we exclude futures contracts with 13 months or greater to maturity because these contracts are typically less liquid. For each sector, we construct an equally weighted portfolio of all commodities in that sector. Finally, we construct an aggregate commodity portfolio as an equally weighted portfolio of the four sectors. The advantage of equally weighting the sectors is that no sector dominates even as the number of commodities within each sector varies over time.

\subsubsection{Currency, bond, and stock markets}

We define a long position on currency futures from the perspective of a US investor that buys foreign currencies. Therefore, a high currency return refers to appreciation of foreign currencies relative to the US dollar. Our construction of the return on a portfolio of currency futures is analogous to our construction of the commodity-sector portfolios. We first compute the return on a fully collateralized position for each futures contract. For each currency, we

compute its monthly gross return as an equally weighted average of returns across currency futures with greater than one and less than 13 months to maturity. Finally, we construct an aggregate currency portfolio as an equally weighted portfolio of all currencies.

For bond and stock markets, we simply use the usual benchmarks for returns, instead of computing these returns based on futures contracts. Bond returns are based on the 10-year US Treasury note. Stock returns are based on the Center for Research in Security Prices (CRSP) value-weighted portfolio of NYSE, Amex, and Nasdaq stocks. 


\subsection{Definition of the predictor variables}

\subsubsection{Commodity market}

Our new predictor of commodity returns is the growth rate of commodity market interest. We examine the growth rate (instead of the level) of open interest because a stochastic trend exists in the data, which we left out of the model in Section 2 for simplicity. To construct this variable, we first compute the dollar open interest for each commodity as the spot price times the quantity of futures contracts outstanding. We then aggregate dollar open interest within each of the four sectors and compute its monthly growth rate. Finally, we compute the aggregate growth rate of open interest as an equally weighted average of the growth rate for each of the four sectors. ${ }^{4}$ Because the monthly growth rate of open interest is noisy, we smooth it by taking a 12-month geometric average in the time series. We also construct a 12-month geometric average of commodity returns, which we use to test for momentum in the time series of commodity returns. ${ }^{5}$

To test the incremental forecasting power of commodity market interest, we examine a number of other variables that are known to predict commodity returns. These other predictor variables can be grouped into two categories. The first category consists of aggregate market predictors, which are motivated by theories such as the intertemporal capital asset pricing model that view the commodity market as being fully integrated (Merton, 1973). We focus on the short rate and the yield spread, which are known to predict the common variation in commodity, bond, and stock returns (Fama and Schwert, 1977; Campbell, 1987; Fama and French, 1989; Bessembinder and Chan, 1992). ${ }^{6}$ The short rate is the monthly

\footnotetext{
${ }^{4}$ We have tried an alternative construction that does not involve the spot price. We first compute the growth rate of open interest (i.e., the quantity of futures contracts outstanding) for each commodity. We then compute the median of the growth rate of open interest across all commodities within each sector. Finally, we compute the aggregate growth rate of open interest as an equally weighted average of the growth rate for each of the four sectors. This alternative construction leads to a time series that is very similar to our preferred construction.

${ }^{5}$ In Hong and Yogo (2011), we also examine the growth rate of trading volume, constructed in an analogous way to the growth rate of open interest, and find that it does not affect the forecasting power of open interest in the subsample since 2002 .

${ }^{6}$ In analysis that is not reported here, we also examine the default spread (i.e., the difference between Moody's Baa and Aaa corporate bond yields) and measures of aggregate stock market volatility (i.e., both
} 
average yield on the one-month T-bill. The yield spread is the difference between Moody's Aaa corporate bond yield and the short rate. In addition to these financial variables, we examine the Chicago Fed National Activity Index as a measure of real economic activity, which is known to predict inflation (Stock and Watson, 1999).

The second category consists of commodity-specific predictors, which are motivated by the view that the commodity market is segmented from other markets. In particular, we examine two measures of supply-demand imbalances in the commodity futures market, motivated by the theory of backwardation. The first measure is an aggregate version of basis, which is known to predict returns on commodity futures (Fama and French, 1987). To construct commodity basis, we first compute basis for each commodity $i$ with maturity $T-t$ as

$$
\operatorname{Basis}_{i, t, T}=\left(\frac{F_{i, t, T}}{S_{i, t}}\right)^{1 /(T-t)}-1 .^{7}
$$

We then compute the median of basis across contracts for each commodity and then the median of basis across commodities for each sector. We use the median, instead of the mean, because it is less sensitive to outliers in basis for individual futures contracts. Finally, we compute commodity basis as an equally weighted average of basis across the four sectors.

The second measure is an aggregate version of a more direct measure of supply-demand imbalances in the commodity futures market that is found in the literature (Carter, Rausser, and Schmitz, 1983; Chang, 1985; Bessembinder, 1992). ${ }^{8}$ We first compute futures market imbalance for each sector as the ratio of two variables. The numerator is the dollar value of short minus long positions held by commercial traders in the Commitments of Traders realized and implied volatility). Although these variables predict returns individually, they have weak incremental forecasting power once we control for the short rate and the yield spread.

${ }^{7}$ While the Commodity Research Bureau has a reliable record of spot prices, a spot price is not always available on the same trading day as a recorded futures price. Whenever the spot price is missing, we first look for an expiring futures contract to impute the spot price. If an expiring futures contract is not available, we then look for the last available spot price within 30 days.

${ }^{8}$ More recently, Acharya, Lochstoer, and Ramadorai (2010) find that the default risk of energy producers, which is an alternative measure of hedging demand, predicts returns on energy futures. 
in Commodity Futures, summed across all commodities in that sector. The denominator is the dollar value of short plus long positions held by commercial traders, summed across all commodities in that sector. We then compute commodity market imbalance as an equally weighted average of futures market imbalance across the four sectors.

\subsubsection{Currency, bond, and stock markets}

For aggregate market predictors of currency, bond, and stock returns, we examine the short rate, the yield spread, and the Chicago Fed National Activity Index. For currency-specific predictors, we examine currency market interest, currency returns, currency basis, and currency market imbalance. For bond-specific predictors, we examine bond market interest, bond returns, and bond market imbalance. For stock-specific predictors, we examine stock market interest, stock returns, stock market imbalance, and the dividend yield on the CRSP value-weighted stock portfolio. The construction of these variables for currency, bond, and stock markets are analogous to our construction of the same variables for the commodity market.

\section{Summary statistics for returns and open interest}

\subsection{Summary statistics for returns}

In Panel A of Table 3, we report summary statistics for monthly excess returns over the one-month T-bill rate in the 1965-2008 sample period. The set of assets for which we have observations on returns in this sample period are the commodity portfolio, the 10-year US Treasury note, and the CRSP value-weighted stock portfolio. The returns on the currency portfolio are available only since 1983 .

Commodities have an average excess return of $0.64 \%$ and a standard deviation of $4.62 \%$. This corresponds to an annualized average excess return of $7.68 \%$ and an annualized standard deviation of $16.00 \%$. For the same sample period, bonds have an annualized average 
excess return of $2.04 \%$ and an annualized standard deviation of $8.00 \%$, and stocks have an annualized average excess return of $4.32 \%$ and an annualized standard deviation of $15.66 \%$. Thus, commodities had a higher realized Sharpe ratio than bonds or stocks (Gorton and Rouwenhorst, 2006). The first-order autocorrelation of monthly excess commodity returns is 0.07 , which is virtually identical to that for bond and stock returns. The correlation between commodity and bond returns is -0.11 , which makes sense in light of the inverse relation between bond prices and inflation. The correlation between commodity and stock returns is 0.06 .

Panel B of Table 3 reports the same statistics in the 1983-2008 subsample, during which we also have observations on currency returns. Commodities have an annualized average excess return of $4.68 \%$ and an annualized standard deviation of $10.88 \%$. For the same sample period, currencies have an annualized average excess return of $1.68 \%$ and an annualized standard deviation of $7.86 \%$. Bonds have an annualized average excess return of $3.96 \%$ and an annualized standard deviation of $7.62 \%$, and stocks have an annualized average excess return of $5.76 \%$ and an annualized standard deviation of $15.35 \%$. The first-order autocorrelation for monthly excess returns is close to 0.1 for all four markets. All four returns are positively correlated with each other, except for the correlation of -0.17 between commodity and bond returns. The correlation of 0.29 between commodity and currency returns is the strongest among the four markets.

\subsection{Summary statistics for the predictor variables}

\subsubsection{Commodity market}

Table 4 reports summary statistics for the predictors of commodity returns in the 19652008 sample period. The 12-month growth rate of commodity market interest has a mean of $1.47 \%$ per month and a standard deviation of $2.06 \%$. The 12 -month commodity returns have a mean of $1.08 \%$ per month and a standard deviation of $1.30 \%$. All the predictor variables are persistent with a monthly autocorrelation of at least 0.90 , except for commodity basis, 
which has a relatively low autocorrelation of 0.79 .

The yield spread is negatively correlated with the Chicago Fed National Activity Index, which confirms the known fact that the yield spread is countercyclical. Commodity market interest is positively correlated with commodity returns, and both variables are positively correlated with the Chicago Fed National Activity Index. Commodity market interest is essentially uncorrelated with commodity basis. However, commodity market interest has a correlation of 0.31 with commodity market imbalance. This means that unusually high commodity market interest tends to coincide with hedgers taking unusually strong short positions in commodity futures.

Figure 2 highlights the cyclicality of commodity market interest, by showing its time series together with the Chicago Fed National Activity Index. During the recent commodity boom, commodity market interest grew over a five-year period from $\$ 62$ billion in June 2003 to $\$ 492$ billion in June 2008. Only the energy crisis of the 1970 s witnessed higher activity. During these two historic periods and also more generally, a high degree of correlation exists between movements in commodity market interest and the Chicago Fed National Activity Index.

\subsubsection{Currency, bond, and stock markets}

Panel A of Table 5 reports summary statistics for the predictors of currency returns in the 1983-2008 sample period. The correlations between the predictors of currency returns are qualitatively similar to those between the predictors of commodity returns in Table 4 . In particular, currency market interest is positively correlated with currency returns, and both variables are positively correlated with the Chicago Fed National Activity Index. In other words, periods of high economic activity are associated with rising currency market interest and high currency returns.

Panel B of Table 5 reports summary statistics for the predictors of bond returns. Bond market interest is positively correlated with the Chicago Fed National Activity Index, and 
bond returns are negatively correlated with the Chicago Fed National Activity Index. That is, periods of high economic activity are associated with rising bond market interest and low bond returns. This inverse relation between economic activity and bond returns makes sense in light of the fact that high economic activity leads to rising inflation expectations, which is bad news for the bond market.

Panel $\mathrm{C}$ of Table 5 reports summary statistics for the predictors of stock returns. The correlations between the predictors of stock returns are qualitatively similar to those between the predictors of commodity returns. In particular, stock market interest is positively correlated with stock returns, and both variables are positively correlated with the Chicago Fed National Activity Index. In other words, periods of high economic activity are associated with rising stock market interest and high stock returns.

Figure 2 highlights the cyclicality of currency, bond, and stock market interest, by showing their time series together with the Chicago Fed National Activity Index. In each of these three markets, strong correlation exists between movements in open interest and the Chicago Fed National Activity Index. Given that movements in open interest are highly pro-cyclical, it is a prime candidate for a predictor of returns. In the next section, we examine whether movements in open interest predict returns even after controlling for other cyclical variables.

\section{Predictability of returns by open interest}

\subsection{Commodity market}

Figure 3 shows the time series of the 12-month growth rate of commodity market interest and 12-month commodity returns. This figure confirms that these two time series are highly correlated. More interesting, this figure reveals that commodity returns look like a version of movements in commodity market interest that is shifted forward by a few months. That is, movements in commodity market interest lead movements in commodity prices in the same direction. 
In Table 6, we formally test the hypothesis that movements in commodity market interest predict commodity returns. In Column 1, we first estimate a baseline specification in which the predictor variables are the short rate, the yield spread, and commodity basis. All coefficients are standardized so that they can be interpreted as the percentage point change in monthly expected returns per 1 standard deviation change in the predictor variable. The short rate enters with a coefficient of -0.51 and a $t$-statistic of -2.42 . More interesting, the yield spread enters with a coefficient of -0.51 and a $t$-statistic of -2.68 . This negative coefficient is in sharp contrast to the positive coefficient found for bonds and stocks (Campbell, 1987; Fama and French, 1989). Because expected commodity returns are low (i.e., commodity prices are high) when the yield spread is high, commodities are a good hedge for time-varying investment opportunities in bond and stock markets. Commodity basis predicts commodity returns with a coefficient of -0.57 and a $t$-statistic of -2.05 . The fact that low commodity basis (i.e., low futures relative to spot price) predicts high returns on being long commodity futures is consistent with the theory of backwardation. Overall, the $R^{2}$ of the forecasting regression is $2.58 \%$.

In Column 2 of Table 6, we introduce commodity market interest to examine its incremental forecasting power for commodity returns. Commodity market interest enters with a coefficient of 0.73 and a $t$-statistic of 2.50. This means that a standard deviation increase in commodity market interest increases expected commodity returns by $0.73 \%$ per month. The coefficients for the other three predictor variables are virtually unchanged from Column 1 because commodity market interest is essentially uncorrelated with these other variables. For this sample period, commodity market interest explains a larger share of the variation in expected commodity returns than the other predictor variables. Moreover, the inclusion of commodity market interest increases the $R^{2}$ of the forecasting regression from $2.58 \%$ to $4.96 \%$.

In Column 3 of Table 6, we introduce past commodity returns to the baseline specification and find that they enter with a coefficient of 0.32 and a $t$-statistic of 1.39. In Column 4, 
we find that commodity market interest drives out the forecasting power of past commodity returns in a horse race between these two variables. Commodity market interest enters with a coefficient of 0.77 and a $t$-statistic of 1.85 , while past commodity returns enter with a statistically insignificant coefficient of -0.08 . This result shows that while commodity market interest and commodity returns are highly correlated, they contain different information about future commodity returns. As shown in Figure 3, commodity market interest tends to lead commodity returns and can, therefore, be more informative.

In Column 5 of Table 6, we introduce commodity market imbalance to the baseline specification and find that it enters with a coefficient of 0.34 and a $t$-statistic of 1.50 . This positive coefficient is consistent with the theory of backwardation, which implies that high hedging demand predicts high returns on being long futures. In Column 6, we find that commodity market interest drives out the forecasting power of commodity market imbalance in a horse race between these two variables. Commodity market interest enters with a coefficient of 0.69 and a $t$-statistic of 2.42 , while commodity market imbalance enters with a statistically insignificant coefficient of 0.12 . As shown in Table 4, commodity market interest and commodity market imbalance are positively correlated. Hence, a potential interpretation of these results is that commodity market imbalance is just a noisy proxy for commodity market interest.

In Column 7 of Table 6, we introduce the Chicago Fed National Activity Index to the baseline specification and find that it enters with a coefficient of 0.47 and a $t$-statistic of 2.09. This positive coefficient is additional evidence that expected commodity returns are pro-cyclical, which is the opposite of countercyclical expected returns found in bond and stock markets. In Column 8, we find that commodity market interest reduces the forecasting power of the Chicago Fed National Activity Index in a horse race between these two variables. Commodity market interest enters with a coefficient of 0.68 and a $t$-statistic of 1.88 , while the Chicago Fed National Activity Index enters with a statistically insignificant coefficient of 0.30 . 
We summarize our main findings in Table 6 as follows. The fact that the short rate, the yield spread, and the Chicago Fed National Activity Index predict commodity returns is consistent with the integrated markets view. That is, the same aggregate factors that drive other asset prices are partly responsible for movements in commodity prices. The fact that commodity basis and commodity market imbalance predict movements in commodity prices is consistent with the segmented markets view. That is, the theory of backwardation is partly responsible for movements in commodity prices. More important, movements in commodity market interest predict movements in commodity prices even after controlling for these other predictors. This finding challenges us to develop a new view of the commodity market that is unrelated to these traditional theories. Our preferred hypothesis is that commodity market interest contains information about the future supply and demand for commodities, which cannot be inferred by commodity prices alone.

In Panel A of Table 7, we show that commodity market interest predicts excess returns on the 10-year US Treasury note over the one-month T-bill rate. In a baseline specification in Column 1, the short rate enters with a statistically insignificant coefficient of 0.20 . The yield spread enters with a coefficient of 0.49 and a $t$-statistic of 3.41 . In Column 2, we introduce commodity market interest to the baseline specification and find that it enters with a coefficient of -0.32 and a $t$-statistic of -3.11 . This means that a standard deviation increase in commodity market interest decreases expected bond returns by $0.32 \%$ per month. The forecasting power of commodity market interest is comparable to that of the yield spread, which is known to be a reliable predictor of bond returns. Column 3 shows that commodity returns predict bond returns, but Column 4 shows that they do not have forecasting power beyond commodity market interest. Similarly, Column 5 shows that the Chicago Fed National Activity Index predicts bond returns, but Column 6 shows that it does not have forecasting power beyond commodity market interest.

In Panel B of Table 7, we show that commodity market interest also predicts movements in the one-month T-bill rate. In a baseline specification in Column 1, the yield spread enters 
with a statistically insignificant coefficient of 0.06. In Column 2, we introduce commodity market interest to the baseline specification and find that it enters with a coefficient of 0.12 and a $t$-statistic of 3.34 . This means that a standard deviation increase in commodity market interest increases the expected annualized short rate by $0.12 \%$. Column 3 shows that commodity returns predict movements in the short rate with a coefficient of 0.12 and a t-statistic of 3.47. In Column 4, commodity market interest and commodity returns enter with similar coefficients in a horse race between these two variables. Column 5 shows that the Chicago Fed National Activity Index predicts movements in the short rate, which is consistent with its ability to predict realized inflation (Stock and Watson, 1999). Column 6 shows that the Chicago Fed National Activity Index does not drive out the forecasting power of commodity market interest.

We summarize our main findings in Table 7 as follows. From Campbell and Ammer (1993), we know that movements in expected excess bond returns are offset by movements in expected inflation. Therefore, the fact that commodity market interest predicts excess bond returns implies that it also captures movements in expected inflation at low frequency. Similarly, movements in the short rate can be interpreted as movements in expected monthly inflation under the Fisher hypothesis. Therefore, the fact that commodity market interest predicts movements in the short rate implies that it also predicts movements in expected inflation at higher frequency. Taken together, this evidence suggests that commodity market interest contains information about inflation expectations that is not captured by conventional predictors of inflation such as commodity prices and the Chicago Fed National Activity Index.

\subsection{Currency market}

Subsection 5.1 shows that movements in commodity market interest predict movements in commodity prices. This subsection shows an analogous relation between currency market interest and exchange rates. The economic rationale for why currency market interest predicts 
movements in exchange rates is analogous to our hypothesis for the commodity market. A strong US economy leads to inflation and consequently depreciation of the US dollar relative to foreign currencies. ${ }^{9}$ Suppose importers expect higher future demand and, in response, enter currency futures to hedge risk arising from higher anticipated imports. Insofar as this good news about the US economy diffuses gradually in the currency market, rising currency market interest predicts high returns on being long foreign currencies.

Table 8 tests whether movements in currency market interest predict currency returns. In Column 1, we first estimate a baseline specification in which the predictor variables are the short rate, the yield spread, and currency basis (i.e., the forward discount). The short rate and the yield spread have little forecasting power for currency returns. However, currency basis predicts currency returns with a coefficient of -0.25 and a $t$-statistic of -1.48 . By the covered interest rate parity, currency basis is the difference in interest rates between the US and foreign countries. Therefore, the negative coefficient means that when the US interest rate is low relative to the rest of the world, foreign currencies are expected to appreciate relative to the US dollar. This failure of the uncovered interest rate parity is known as the forward-discount puzzle in international finance.

In Column 2 of Table 8, we introduce currency market interest to examine its incremental forecasting power for currency returns. Currency market interest enters with a coefficient of 0.37 and a $t$-statistic of 2.48. This means that a standard deviation increase in currency market interest increases expected currency returns by $0.37 \%$ per month. Figure 3 is a visual representation of this finding. Throughout the sample period, movements in currency market interest tend to lead movements in currency returns, except perhaps for a period in the 1990s. The coefficient for currency market interest is larger in economic magnitude than that for currency basis. Moreover, the inclusion of currency market interest increases the

\footnotetext{
${ }^{9}$ More formally, a positive US productivity shock leads to depreciation of the US dollar relative to foreign currencies in a standard Ricardian model of bilateral trade (Backus, Kehoe, and Kydland, 1994). The intuition for this result is that a positive US productivity shock makes goods produced by the US relatively abundant, so that the price of these goods must fall relative to the price of goods produced by foreign countries.
} 
$R^{2}$ of the forecasting regression from $2.03 \%$ to $4.55 \%$. These findings suggest that currency market interest is a more important determinant of exchange rates than currency basis.

In Column 3 of Table 8, we introduce past currency returns to the baseline specification and find that they enter with a coefficient of 0.26 and a $t$-statistic of 1.51 . That is, some evidence exists for momentum in the time series of currency returns, similar to one that is found for commodity returns (Moskowitz, Ooi, and Pedersen, 2010). In Column 4, we find that currency market interest weakens the forecasting power of currency returns in a horse race between these two variables. Currency market interest enters with a coefficient of 0.32 and a $t$-statistic of 2.18 , while currency returns enter with a statistically insignificant coefficient of 0.12 .

In Column 5 of Table 8, we introduce currency market imbalance to the baseline specification and find that it enters with a coefficient of 0.25 and a $t$-statistic of 1.98 . This positive coefficient is consistent with the theory of backwardation, which implies that high hedging demand predicts high returns on being long futures. In Column 6, we find that currency market interest drives out the forecasting power of currency market imbalance in a horse race between these two variables. Currency market interest enters with a coefficient of 0.33 and a $t$-statistic of 2.25 , while currency market imbalance enters with a statistically insignificant coefficient of 0.15 .

In Column 7 of Table 8, we introduce the Chicago Fed National Activity Index to the baseline specification and find that it enters with a coefficient of 0.32 and a $t$-statistic of 1.41. This positive coefficient is consistent with the hypothesis that a strong US economy leads to inflation and consequently depreciation of the US dollar relative to foreign currencies. In Column 8, we find that currency market interest drives out the forecasting power of the Chicago Fed National Activity Index in a horse race between these two variables. Currency market interest enters with a coefficient of 0.32 and a $t$-statistic of 2.24, while the Chicago Fed National Activity Index enters with a statistically insignificant coefficient of 0.24. 


\subsection{Bond market}

Table 9 tests whether movements in bond market interest predict bond returns. In Column 1, we first estimate a baseline specification in which the predictor variables are the short rate and the yield spread. The short rate enters with a statistically insignificant coefficient of 0.20 . However, the yield spread is a powerful predictor of bond returns with a coefficient of 0.34 and a $t$-statistic of 2.39 .

In Column 2 of Table 9, we introduce bond market interest and find that it enters with a coefficient of -0.31 and a $t$-statistic of -1.91 . This means that a standard deviation increase in bond market interest decreases expected bond returns by $0.31 \%$ per month. To interpret the sign of this coefficient, recall from Table 5 that bond market interest is positively correlated with the Chicago Fed National Activity Index. A high Chicago Fed National Activity Index signals inflation, which is bad news for bonds.

In Columns 3 and 4 of Table 9, we find that past bond returns do not have forecasting power for future bond returns. Similarly, Columns 5 and 6 show that bond market imbalance does not have forecasting power for bond returns. In Column 7, we introduce the Chicago Fed National Activity Index to the baseline specification and find that it enters with a coefficient of -0.31 and a $t$-statistic of -1.96 . In Column 8 , we find that the Chicago Fed National Activity Index slightly weakens the forecasting power of bond market interest in a horse race between these two variables. Given that bond market interest and the Chicago Fed National Activity Index both signal inflation, these findings are consistent with our hypothesis.

\subsection{Stock market}

Table 10 tests whether movements in stock market interest predict stock returns. Column 1 is our baseline specification in which the predictor variables are the short rate, the yield spread, and the dividend yield. None of these variables, which are known to predict stock returns, is statistically significant in the 1984-2008 sample period. This is perhaps not surprising given that stock returns are notoriously difficult to predict, especially in a short 
sample period that includes the unusual stock market behavior of the late 1990s. Hence, the results that follow for stock market interest should be interpreted with this caveat in mind.

In Column 2 of Table 10, we introduce stock market interest to our baseline specification and find that it enters with a coefficient of 0.38 and a $t$-statistic of 1.38 . This means that a standard deviation increase in stock market interest increases expected stock returns by $0.38 \%$ per month. Although this coefficient is not statistically significant in this sample period, the economic magnitude of the coefficient is comparable to that for the short rate, the yield spread, and the dividend yield.

In Columns 3 and 4 of Table 10, we find that past stock returns do not have forecasting power for future stock returns. In Column 5, we introduce stock market imbalance to our baseline specification and find that it enters with a coefficient of -0.45 and a $t$-statistic of -1.80. In Column 6, we find that stock market interest enters with a coefficient of 0.50 and a $t$-statistic of 1.76 in a specification that controls for stock market imbalance. In Column 7, we introduce the Chicago Fed National Activity Index to our baseline specification and find that it enters with a coefficient of 0.70 and a $t$-statistic of 1.97 . In Column 8 , we find that the Chicago Fed National Activity Index weakens the forecasting power of stock market interest in a horse race between these two variables.

\section{Conclusion}

Commodity market interest is a more powerful predictor of commodity returns, bond returns, and movements in the short rate than past commodity prices or the Chicago Fed National Activity Index. Our findings have broader implications for the large macro literature on inflation forecasting. Macroeconomists have already known for some time that asset prices can be useful for forecasting inflation and output (Stock and Watson, 2003). These forecasting models generally assume that asset prices contain timely information about economic activity and inflation expectations. However, our findings suggest that asset prices initially 
underreact to news about economic activity and inflation expectations, which are better captured by open interest. Our work opens up a new approach to inflation forecasting, in which commodity market interest could be used to improve the forecasting power of existing models.

Our work also opens up a new approach to modeling expected returns in financial economics. Most empirical models of expected returns are premised on the notion that past prices contain all useful information for forecasting future returns, whether such predictability arises from a time-varying risk premium or limits to arbitrage. Our work shows that transaction quantities, in particular open interest in the futures market, contain information that is not fully revealed by transaction prices alone. The idea that transaction quantities could be more informative than transaction prices is entirely new and offers a richer understanding of movements in asset prices. 


\section{References}

Acharya, V. V., Lochstoer, L. A., Ramadorai, T., 2010. Limits to arbitrage and hedging: Evidence from commodity markets. Unpublished working paper. New York University.

Backus, D. K., Kehoe, P. J., Kydland, F. E., 1994. Dynamics of the trade balance and the terms of trade: The J-curve? American Economic Review 84 (1), 84-103.

Bessembinder, H., 1992. Systematic risk, hedging pressure, and risk premiums in futures markets. Review of Financial Studies 5 (4), 637-667.

Bessembinder, H., Chan, K., 1992. Time-varying risk premia and forecastable returns in futures markets. Journal of Financial Economics 32 (2), 169-193.

Campbell, J. Y., 1987. Stock returns and the term structure. Journal of Financial Economics 18 (2), 373-399.

Campbell, J. Y., Ammer, J., 1993. What moves the stock and bond markets? A variance decomposition for long-term asset returns. Journal of Finance 48 (1), 3-37.

Carter, C. A., Rausser, G. C., Schmitz, A., 1983. Efficient asset portfolios and the theory of normal backwardation. Journal of Political Economy 91 (2), 319-331.

Chang, E. C., 1985. Returns to speculators and the theory of normal backwardation. Journal of Finance 40 (1), 193-208.

Commodity Exchange Authority, 1964-1972. Commodity Futures Statistics. US Government Printing Office, Washington, DC.

Commodity Futures Trading Commission, 1972-1985. Commitments of Traders in Commodity Futures. Commodity Futures Trading Commission, New York.

De Long, J. B., Shleifer, A., Summers, L. H., Waldmann, R. J., 1990. Noise trader risk in financial markets. Journal of Political Economy 98 (4), 703-738. 
Fama, E. F., French, K. R., 1987. Commodity futures prices: Some evidence on forecast power, premiums, and the theory of storage. Journal of Business 60 (1), 55-73.

Fama, E. F., French, K. R., 1989. Business conditions and expected returns on stocks and bonds. Journal of Financial Economics 25 (1), 23-49.

Fama, E. F., Schwert, G. W., 1977. Asset returns and inflation. Journal of Financial Economics 5 (2), 115-146.

Gorton, G., Rouwenhorst, K. G., 2006. Facts and fantasies about commodity futures. Financial Analysts Journal 62 (2), 47-68.

Gourinchas, P.-O., Tornell, A., 2004. Exchange rate puzzles and distorted beliefs. Journal of International Economics 64 (2), 303-333.

Grossman, S. J., 1977. The existence of futures markets, noisy rational expectations and informational externalities. Review of Economic Studies 44 (3), 431-449.

Hicks, J. R., 1939. Value and Capital: An Inquiry into Some Fundamental Principles of Economic Theory. Clarendon Press, Oxford.

Hong, H., Stein, J. C., 1999. A unified theory of underreaction, momentum trading, and overreaction in asset markets. Journal of Finance 54 (6), 2143-2184.

Hong, H., Stein, J. C., 2007. Disagreement and the stock market. Journal of Economic Perspectives 21 (2), 109-128.

Hong, H., Yogo, M., 2011. Appendix to "What does futures market interest tell us about the macroeconomy and asset prices?". Unpublished working paper. Federal Reserve Bank of Minneapolis.

Keynes, J. M., 1923. Some aspects of commodity markets. Manchester Guardian Commercial 13, 784-786. 
Mankiw, N. G., Reis, R., 2002. Sticky information versus sticky prices: A proposal to replace the New Keynesian Phillips curve. Quarterly Journal of Economics 117 (4), 1295-1328.

Merton, R. C., 1973. An intertemporal capital asset pricing model. Econometrica 41 (5), 867-887.

Moskowitz, T. J., Ooi, Y. H., Pedersen, L. H., 2010. Time series momentum. Unpublished working paper. University of Chicago.

Samuelson, P. A., 1965. Proof that properly anticipated prices fluctuate randomly. Industrial Management Review 6 (2), 41-49.

Shleifer, A., 1986. Do demand curves for stocks slope down? Journal of Finance 41 (3), 579-590.

Stock, J. H., Watson, M. W., 1999. Forecasting inflation. Journal of Monetary Economics 44 (2), 293-335.

Stock, J. H., Watson, M. W., 2003. Forecasting output and inflation: The role of asset prices. Journal of Economic Literature 41 (3), 788-829. 
Table 1: Commodity market futures

The 30 commodity futures used in our analysis, for which futures and spot prices are available through the Commodity Research Bureau, are listed. The futures contracts are traded on the Chicago Board of Trade (CBOT), the Chicago Mercantile Exchange (CME), the Intercontinental Exchange (ICE), and the New York Mercantile Exchange (NYMEX). The sample starts in December 1964, after which prices are available for many commodities.

\begin{tabular}{|c|c|c|c|c|}
\hline \multirow[b]{2}{*}{ Sector } & \multirow[b]{2}{*}{ Commodity } & \multirow[b]{2}{*}{ Exchange } & \multicolumn{2}{|c|}{ First observation } \\
\hline & & & Futures price & $\begin{array}{r}\text { Commitments of Traders } \\
\text { in Commodity Futures }\end{array}$ \\
\hline \multirow[t]{14}{*}{ Agriculture } & Butter & $\mathrm{CME}$ & September 1996 & May 1997 \\
\hline & Cocoa & ICE & December 1964 & July 1978 \\
\hline & Coffee & $\mathrm{ICE}$ & August 1972 & July 1978 \\
\hline & Corn & CBOT & December 1964 & December 1964 \\
\hline & Cotton & $\mathrm{ICE}$ & December 1964 & December 1964 \\
\hline & Lumber & CME & October 1969 & July 1978 \\
\hline & Oats & CBOT & December 1964 & December 1964 \\
\hline & Orange juice & $\mathrm{ICE}$ & February 1967 & January 1969 \\
\hline & Rough rice & $\mathrm{CBOT}$ & August 1986 & October 1986 \\
\hline & Soybean meal & CBOT & December 1964 & December 1964 \\
\hline & Soybean oil & CBOT & December 1964 & December 1964 \\
\hline & Soybeans & CBOT & December 1964 & December 1964 \\
\hline & Sugar & ICE & December 1964 & July 1978 \\
\hline & Wheat & CBOT & December 1964 & December 1964 \\
\hline \multirow[t]{5}{*}{ Energy } & Crude oil & NYMEX & March 1983 & April 1983 \\
\hline & Gasoline & NYMEX & December 1984 & December 1984 \\
\hline & Heating oil & NYMEX & November 1978 & October 1980 \\
\hline & Natural gas & NYMEX & April 1990 & April 1990 \\
\hline & Propane & NYMEX & August 1987 & August 1987 \\
\hline \multirow[t]{5}{*}{ Livestock } & Broilers & $\mathrm{CME}$ & February 1991 & March 1991 \\
\hline & Feeder cattle & $\mathrm{CME}$ & November 1971 & December 1975 \\
\hline & Live/Lean hogs & $\mathrm{CME}$ & February 1966 & July 1968 \\
\hline & Live cattle & $\mathrm{CME}$ & December 1964 & July 1968 \\
\hline & Pork bellies & $\mathrm{CME}$ & December 1964 & July 1968 \\
\hline \multirow[t]{6}{*}{ Metals } & Aluminum & NYMEX & December 1983 & January 1984 \\
\hline & Copper & NYMEX & December 1964 & December 1982 \\
\hline & Gold & NYMEX & December 1974 & December 1982 \\
\hline & Palladium & NYMEX & January 1977 & July 1978 \\
\hline & Platinum & NYMEX & March 1968 & July 1978 \\
\hline & Silver & NYMEX & December 1964 & December 1982 \\
\hline
\end{tabular}


Table 2: Currency, bond, and stock market futures

The eight currency, 10 bond, and 14 stock futures used in our analysis, for which futures and spot prices are available through the Commodity Research Bureau, are listed. The futures contracts are traded on the Chicago Board of Trade (CBOT), the Index and Option Market (IOM), the Intercontinental Exchange (ICE), the International Monetary Market (IMM), and the Kansas City Board of Trade (KCBT). The sample starts in December 1982 because the Commitments of Traders in Commodity Futures were not available between January and November 1982, and these futures markets were relatively small prior to that date.

\begin{tabular}{|c|c|c|c|c|}
\hline \multirow[b]{2}{*}{ Market } & \multirow[b]{2}{*}{ Financial asset } & \multirow[b]{2}{*}{ Exchange } & \multicolumn{2}{|c|}{ First observation } \\
\hline & & & Futures price & $\begin{array}{l}\text { Commitments of Traders } \\
\text { in Commodity Futures }\end{array}$ \\
\hline \multirow[t]{8}{*}{ Currency } & Australian dollar & IMM & January 1987 & January 1987 \\
\hline & British pound & IMM & December 1982 & December 1982 \\
\hline & Canadian dollar & IMM & December 1982 & December 1982 \\
\hline & Deutsche mark & IMM & December 1982 & December 1982 \\
\hline & Euro & IMM & May 1998 & January 1999 \\
\hline & Japanese yen & IMM & December 1982 & December 1982 \\
\hline & New Zealand dollar & IMM & May 1997 & January 1999 \\
\hline & Swiss franc & IMM & December 1982 & December 1982 \\
\hline \multirow[t]{10}{*}{ Bond } & 30-day federal funds & $\mathrm{CBOT}$ & October 1988 & October 1988 \\
\hline & One-month Eurodollar & IMM & May 1990 & May 1990 \\
\hline & Three-month Eurodollar & IMM & December 1982 & December 1982 \\
\hline & Three-month US Treasury bill & IMM & December 1982 & December 1982 \\
\hline & Two-year US Treasury note & CBOT & June 1990 & June 1990 \\
\hline & Five-year US Treasury note & $\mathrm{CBOT}$ & May 1988 & May 1988 \\
\hline & Five-year US Treasury note swap & CBOT & June 2002 & February 2003 \\
\hline & 10-year US Treasury note & $\mathrm{CBOT}$ & December 1982 & December 1982 \\
\hline & 10-year US Treasury note swap & $\mathrm{CBOT}$ & October 2001 & November 2001 \\
\hline & 30-year US Treasury bond & $\mathrm{CBOT}$ & December 1982 & December 1982 \\
\hline \multirow[t]{14}{*}{ Stock } & Dow Jones Industrial Index & CBOT & October 1997 & October 1997 \\
\hline & Major Market Index & IOM & August 1985 & October 1991 \\
\hline & Nasdaq 100 Index & IOM & April 1996 & April 1996 \\
\hline & Nasdaq 100 Index E-Mini & IOM & June 1999 & June 1999 \\
\hline & NYSE Composite Index & ICE & December 1982 & December 1982 \\
\hline & Russell 2000 Index & IOM & February 1993 & February 1993 \\
\hline & Russell 2000 Index E-Mini & IOM & November 2001 & August 2002 \\
\hline & Standard \& Poor's 400 MidCap Index & IOM & February 1992 & February 1992 \\
\hline & Standard \& Poor's 400 MidCap Index E-Mini & IOM & January 2002 & November 2002 \\
\hline & Standard \& Poor's 500 Barra Value Index & IOM & November 1995 & April 1996 \\
\hline & Standard \& Poor's 500 Barra Growth Index & IOM & November 1995 & December 1995 \\
\hline & Standard \& Poor's 500 Index & IOM & April 1982 & October 1983 \\
\hline & Standard \& Poor's 500 Index E-Mini & IOM & September 1997 & September 1997 \\
\hline & Value-Line Arithmetic Index & KCBT & September 1983 & October 1983 \\
\hline
\end{tabular}


Table 3: Summary statistics for commodity, currency, bond, and stock returns

The mean, the standard deviation, the autocorrelation, and the pairwise correlation of monthly excess returns over the one-month T-bill rate are reported. The portfolio of fully collateralized commodity futures is equally weighted across agriculture, energy, livestock, and metals. The portfolio of fully collateralized currency futures is equally weighted across the eight currencies listed in Table 2. The other assets are the 10-year US Treasury note and the Center for Research in Security Prices value-weighted stock portfolio.

\begin{tabular}{|c|c|c|c|c|c|c|}
\hline \multirow[b]{2}{*}{ Variable } & \multirow[b]{2}{*}{$\begin{array}{r}\text { Mean } \\
(\%)\end{array}$} & \multirow{2}{*}{$\begin{array}{r}\text { Standard } \\
\text { deviation } \\
(\%)\end{array}$} & \multirow[b]{2}{*}{ Autocorrelation } & \multicolumn{3}{|c|}{ Correlation with } \\
\hline & & & & $\begin{array}{r}\text { Commodity } \\
\text { portfolio }\end{array}$ & $\begin{array}{l}\text { Currency } \\
\text { portfolio }\end{array}$ & $\begin{array}{r}\text { 10-year } \\
\text { bond }\end{array}$ \\
\hline \multicolumn{7}{|c|}{ Panel A: 1965:1-2008:12 } \\
\hline Commodity portfolio & 0.64 & 4.62 & 0.07 & & & \\
\hline 10-year bond & 0.17 & 2.31 & 0.08 & -0.11 & & \\
\hline Stock portfolio & 0.36 & 4.52 & 0.09 & 0.06 & & 0.18 \\
\hline \multicolumn{7}{|c|}{ Panel B: 1983:1-2008:12 } \\
\hline Commodity portfolio & 0.39 & 3.14 & 0.14 & & & \\
\hline Currency portfolio & 0.14 & 2.27 & 0.11 & 0.29 & & \\
\hline 10-year bond & 0.33 & 2.20 & 0.07 & -0.17 & 0.16 & \\
\hline Stock portfolio & 0.48 & 4.43 & 0.10 & 0.16 & 0.07 & 0.06 \\
\hline
\end{tabular}


Table 4: Summary statistics for predictors of commodity returns

The mean, the standard deviation, the autocorrelation, and the pairwise correlation for predictors of commodity returns are reported. The short rate is the monthly average yield on the one-month T-bill. The yield spread is the difference between Moody's Aaa corporate bond yield and the short rate. The Chicago Fed National Activity Index is a weighted average of 85 monthly indicators of US economic activity. The next predictor variables are the 12-month geometrically averaged growth rate of commodity market interest and the 12-month geometrically averaged commodity returns. Commodity market imbalance is the ratio of short minus long positions relative to short plus long positions held by commercial traders in the Commitments of Traders in Commodity Futures. Commodity basis is equally weighted across agriculture, energy, livestock, and metals. The ن sample period is 1965:12-2008:12.

\begin{tabular}{|c|c|c|c|c|c|c|c|c|c|}
\hline \multirow[b]{2}{*}{ Variable } & \multirow[b]{2}{*}{$\begin{array}{r}\text { Mean } \\
(\%)\end{array}$} & \multirow{2}{*}{$\begin{array}{r}\text { Standard } \\
\text { deviation } \\
(\%)\end{array}$} & \multirow[b]{2}{*}{ Autocorrelation } & \multicolumn{6}{|c|}{ Correlation with } \\
\hline & & & & $\begin{array}{r}\text { Short } \\
\text { rate }\end{array}$ & $\begin{array}{r}\text { Yield } \\
\text { spread }\end{array}$ & $\begin{array}{r}\text { Chicago Fed National } \\
\text { Activity Index }\end{array}$ & $\begin{array}{r}\text { Commodity } \\
\text { market interest }\end{array}$ & $\begin{array}{r}\text { Commodity } \\
\text { returns }\end{array}$ & $\begin{array}{r}\text { Commodity } \\
\text { basis }\end{array}$ \\
\hline Short rate & 5.52 & 2.71 & 0.97 & & & & & & \\
\hline Yield spread & 2.64 & 1.60 & 0.92 & -0.54 & & & & & \\
\hline Chicago Fed National Activity Index & 0.01 & 0.86 & 0.93 & -0.02 & -0.12 & & & & \\
\hline Commodity market interest & 1.47 & 2.06 & 0.90 & 0.01 & -0.10 & 0.36 & & & \\
\hline Commodity returns & 1.08 & 1.30 & 0.93 & 0.05 & -0.35 & 0.29 & 0.51 & & \\
\hline Commodity basis & 0.14 & 0.62 & 0.79 & 0.24 & -0.24 & -0.11 & -0.07 & 0.03 & \\
\hline Commodity market imbalance & 17.84 & 13.80 & 0.90 & 0.27 & -0.31 & 0.17 & 0.31 & 0.44 & 0.15 \\
\hline
\end{tabular}


Table 5: Summary statistics for predictors of currency, bond, and stock returns

Panel A reports the mean, the standard deviation, the autocorrelation, and the pairwise correlation for predictors of currency returns. The short rate is the monthly average yield on the one-month T-bill. The yield spread is the difference between Moody's Aaa corporate bond yield and the short rate. The Chicago Fed National Activity Index is a weighted average of 85 monthly indicators of US economic activity. The next predictor variables are the 12-month geometrically averaged growth rate of currency market interest and the 12-month geometrically averaged currency returns. Currency market imbalance is the ratio of short minus long positions relative to short plus long positions held by commercial traders in the Commitments of Traders in Commodity Futures. Currency basis is equally weighted across the eight currencies listed in Table 2. Panels B and C report summary statistics for analogous predictor variables in bond and stock markets. The sample period is 1983:12-2008:12.

\begin{tabular}{|c|c|c|c|c|c|c|c|c|c|}
\hline \multirow[b]{2}{*}{ Variable } & \multirow[b]{2}{*}{$\begin{array}{r}\text { Mean } \\
(\%)\end{array}$} & \multirow{2}{*}{$\begin{array}{r}\text { Standard } \\
\text { deviation } \\
(\%)\end{array}$} & \multirow[b]{2}{*}{ Autocorrelation } & \multicolumn{6}{|c|}{ Correlation with } \\
\hline & & & & $\begin{array}{l}\text { Short } \\
\text { rate }\end{array}$ & $\begin{array}{r}\text { Yield } \\
\text { spread }\end{array}$ & $\begin{array}{r}\text { Chicago Fed National } \\
\text { Activity Index }\end{array}$ & $\begin{array}{l}\text { Market } \\
\text { interest }\end{array}$ & Returns & Basis \\
\hline \multicolumn{10}{|l|}{ Panel A: Currency market } \\
\hline Short rate & 4.58 & 2.14 & 0.98 & & & & & & \\
\hline Yield spread & 3.16 & 1.35 & 0.94 & -0.48 & & & & & \\
\hline Chicago Fed National Activity Index & -0.04 & 0.61 & 0.94 & 0.27 & -0.08 & & & & \\
\hline Currency market interest & 0.92 & 1.94 & 0.75 & -0.08 & -0.01 & 0.18 & & & \\
\hline Currency returns & 0.57 & 0.78 & 0.94 & -0.11 & 0.21 & 0.02 & 0.41 & & \\
\hline Currency basis & 0.01 & 0.14 & 0.97 & 0.54 & -0.32 & 0.50 & -0.06 & -0.24 & \\
\hline Currency market imbalance & 6.81 & 26.61 & 0.66 & 0.00 & 0.24 & 0.10 & 0.25 & 0.43 & 0.09 \\
\hline \multicolumn{10}{|l|}{ Panel B: Bond market } \\
\hline Bond market interest & 1.66 & 1.59 & 0.93 & 0.21 & 0.28 & 0.26 & & & \\
\hline Bond returns & 0.69 & 0.67 & 0.92 & 0.05 & 0.08 & -0.31 & 0.01 & & \\
\hline Bond market imbalance & 0.87 & 6.95 & 0.91 & -0.28 & 0.24 & -0.54 & -0.08 & 0.29 & \\
\hline \multicolumn{10}{|l|}{ Panel C: Stock market } \\
\hline Stock market interest & 1.72 & 1.88 & 0.88 & 0.35 & -0.09 & 0.32 & & & \\
\hline Stock returns & 0.66 & 1.29 & 0.91 & 0.25 & -0.38 & 0.46 & 0.61 & & \\
\hline Stock market imbalance & -1.06 & 8.50 & 0.72 & -0.08 & 0.09 & -0.05 & 0.18 & -0.11 & \\
\hline
\end{tabular}


Table 6: Predictability of commodity returns by commodity market interest

The predictability of monthly excess returns on a portfolio of fully collateralized commodity futures over the one-month T-bill rate is tested. All predictor variables are lagged one month. The table reports standardized coefficients with heteroskedasticityconsistent $t$-statistics in parentheses. The sample period is 1966:1-2008:12.

\begin{tabular}{|c|c|c|c|c|c|c|c|c|}
\hline Predictor variable & (1) & $(2)$ & $(3)$ & $(4)$ & $(5)$ & (6) & $(7)$ & (8) \\
\hline \multirow[t]{2}{*}{ Short rate } & -0.51 & -0.48 & -0.44 & -0.50 & -0.55 & -0.50 & -0.52 & -0.55 \\
\hline & $(-2.42)$ & $(-1.85)$ & $(-2.10)$ & $(-1.98)$ & $(-2.39)$ & $(-1.99)$ & $(-2.50)$ & $(-2.12)$ \\
\hline \multirow[t]{2}{*}{ Yield spread } & -0.51 & -0.44 & -0.37 & -0.48 & -0.45 & -0.42 & -0.58 & -0.57 \\
\hline & $(-2.68)$ & $(-2.03)$ & $(-2.03)$ & $(-2.41)$ & $(-2.17)$ & $(-1.90)$ & $(-2.78)$ & $(-2.54)$ \\
\hline \multirow{2}{*}{ Commodity basis } & -0.57 & -0.52 & -0.56 & -0.52 & -0.59 & -0.53 & -0.66 & -0.62 \\
\hline & $(-2.05)$ & $(-1.91)$ & $(-2.01)$ & $(-1.91)$ & $(-2.04)$ & $(-1.92)$ & $(-2.02)$ & $(-1.88)$ \\
\hline \multirow[t]{2}{*}{ Commodity market interest } & & 0.73 & & 0.77 & & 0.69 & & 0.68 \\
\hline & & $(2.50)$ & & $(1.85)$ & & $(2.42)$ & & $(1.88)$ \\
\hline \multirow[t]{2}{*}{ Commodity returns } & & & 0.32 & -0.08 & & & & \\
\hline & & & $(1.39)$ & $(-0.22)$ & & & & \\
\hline \multirow[t]{2}{*}{ Commodity market imbalance } & & & & & 0.34 & 0.12 & & \\
\hline & & & & & $(1.50)$ & $(0.60)$ & & \\
\hline \multirow[t]{2}{*}{ Chicago Fed National Activity Index } & & & & & & & 0.47 & 0.30 \\
\hline & & & & & & & $(2.09)$ & $(0.93)$ \\
\hline$R^{2}(\%)$ & 2.58 & 4.96 & 2.98 & 4.98 & 3.01 & 5.02 & 4.26 & 6.20 \\
\hline
\end{tabular}


Table 7: Predictability of bond returns and movements in the short rate by commodity market interest

Panel A tests the predictability of monthly excess returns on the 10-year US Treasury note over the one-month T-bill rate. Panel B tests the predictability of movements in the onemonth T-bill rate. All predictor variables are lagged one month. The table reports standardized coefficients with heteroskedasticity-consistent $t$-statistics in parentheses. The sample period is 1966:1-2008:12.

\begin{tabular}{lrrrrrr}
\hline Predictor variable & $(1)$ & $(2)$ & $(3)$ & $(4)$ & $(5)$ & $(6)$ \\
\hline Panel A: Bond returns & & & & & & \\
Short rate & 0.20 & 0.14 & 0.15 & 0.13 & 0.19 & 0.15 \\
& $(1.26)$ & $(0.79)$ & $(0.95)$ & $(0.72)$ & $(1.19)$ & $(0.78)$ \\
Yield spread & 0.49 & 0.38 & 0.38 & 0.35 & 0.48 & 0.38 \\
& $(3.41)$ & $(2.65)$ & $(2.62)$ & $(2.39)$ & $(3.15)$ & $(2.45)$ \\
Commodity market interest & & -0.32 & & -0.28 & & -0.33 \\
& & $(-3.11)$ & & $(-2.35)$ & & $(-3.07)$ \\
Commodity returns & & & -0.24 & -0.09 & & \\
& & & $(-1.99)$ & $(-0.62)$ & & \\
Chicago Fed National Activity Index & & & & & -0.20 & -0.04 \\
& 3.15 & 4.26 & 4.03 & 4.35 & 3.96 & 4.63 \\
$R^{2}$ (\%) & & & & & & \\
Panel B: Movements in the short rate & 0.06 & 0.07 & 0.10 & 0.09 & 0.07 & 0.08 \\
Yield spread & $(1.22)$ & $(1.42)$ & $(2.09)$ & $(1.89)$ & $(1.43)$ & $(1.48)$ \\
& & 0.12 & & 0.08 & & 0.09 \\
Commodity market interest & & $(3.34)$ & & $(1.77)$ & & $(2.66)$ \\
& & & 0.12 & 0.07 & & \\
Commodity returns & & & $(3.47)$ & $(1.46)$ & & \\
Chicago Fed National Activity Index & & & & & 0.12 & 0.09 \\
& & & & & $(3.07)$ & $(2.19)$ \\
$R^{2}$ (\%) & 0.74 & 4.02 & 3.74 & 4.81 & 3.94 & 5.68 \\
\hline
\end{tabular}


Table 8: Predictability of currency returns by currency market interest

The predictability of monthly excess returns on a portfolio of fully collateralized currency futures over the one-month T-bill rate is tested. All predictor variables are lagged one month. The table reports standardized coefficients with heteroskedasticityconsistent $t$-statistics in parentheses. The sample period is 1984:1-2008:12.

\begin{tabular}{|c|c|c|c|c|c|c|c|c|}
\hline Predictor variable & (1) & $(2)$ & $(3)$ & (4) & $(5)$ & (6) & $(7)$ & (8) \\
\hline \multirow[t]{2}{*}{ Short rate } & 0.06 & 0.09 & 0.03 & 0.08 & 0.04 & 0.08 & 0.05 & 0.08 \\
\hline & $(0.30)$ & $(0.52)$ & $(0.17)$ & $(0.42)$ & $(0.21)$ & $(0.44)$ & $(0.27)$ & $(0.47)$ \\
\hline \multirow[t]{2}{*}{ Yield spread } & 0.19 & 0.21 & 0.14 & 0.19 & 0.11 & 0.16 & 0.16 & 0.18 \\
\hline & $(1.12)$ & $(1.25)$ & $(0.80)$ & $(1.05)$ & $(0.64)$ & $(0.93)$ & $(0.86)$ & $(1.02)$ \\
\hline \multirow{2}{*}{ Currency basis } & -0.25 & -0.24 & -0.19 & -0.21 & -0.29 & -0.26 & -0.42 & -0.36 \\
\hline & $(-1.48)$ & $(-1.43)$ & $(-1.11)$ & $(-1.25)$ & $(-1.70)$ & $(-1.57)$ & $(-1.86)$ & $(-1.61)$ \\
\hline \multirow[t]{2}{*}{ Currency market interest } & & 0.37 & & 0.32 & & 0.33 & & 0.32 \\
\hline & & $(2.48)$ & & $(2.18)$ & & $(2.25)$ & & $(2.24)$ \\
\hline \multirow[t]{2}{*}{ Currency returns } & & & 0.26 & 0.12 & & & & \\
\hline & & & $(1.51)$ & $(0.71)$ & & & & \\
\hline \multirow[t]{2}{*}{ Currency market imbalance } & & & & & 0.25 & 0.15 & & \\
\hline & & & & & (1.98) & $(1.28)$ & & \\
\hline \multirow[t]{2}{*}{ Chicago Fed National Activity Index } & & & & & & & 0.32 & 0.24 \\
\hline & & & & & & & (1.41) & $(1.02)$ \\
\hline$R^{2}(\%)$ & 2.03 & 4.55 & 3.19 & 4.77 & 3.07 & 4.90 & 3.47 & 5.28 \\
\hline
\end{tabular}


Table 9: Predictability of bond returns by bond market interest

The predictability of monthly excess returns on the 10-year US Treasury note over the one-month T-bill rate is tested. All predictor variables are lagged one month. The table reports standardized coefficients with heteroskedasticity-consistent $t$ statistics in parentheses. The sample period is 1984:1-2008:12.

\begin{tabular}{|c|c|c|c|c|c|c|c|c|}
\hline Predictor variable & $(1)$ & $(2)$ & $(3)$ & (4) & $(5)$ & $(6)$ & $(7)$ & (8) \\
\hline \multirow[t]{2}{*}{ Short rate } & 0.20 & 0.34 & 0.20 & 0.33 & 0.22 & 0.34 & 0.29 & 0.39 \\
\hline & $(1.18)$ & $(1.92)$ & $(1.11)$ & $(1.84)$ & $(1.25)$ & $(1.95)$ & $(1.81)$ & $(2.28)$ \\
\hline \multirow[t]{2}{*}{ Yield spread } & 0.34 & 0.50 & 0.33 & 0.49 & 0.33 & 0.49 & 0.36 & 0.49 \\
\hline & $(2.39)$ & $(3.00)$ & $(2.26)$ & $(2.87)$ & $(2.34)$ & $(2.95)$ & $(2.56)$ & $(3.05)$ \\
\hline \multirow[t]{2}{*}{ Bond market interest } & & -0.31 & & -0.31 & & -0.31 & & -0.26 \\
\hline & & $(-1.91)$ & & $(-1.89)$ & & $(-1.88)$ & & $(-1.66)$ \\
\hline \multirow[t]{2}{*}{ Bond returns } & & & 0.06 & 0.05 & & & & \\
\hline & & & $(0.45)$ & $(0.36)$ & & & & \\
\hline Bond market imbalance & & & & & $\begin{array}{r}0.06 \\
(0.47)\end{array}$ & $\begin{array}{r}0.04 \\
(0.30)\end{array}$ & & \\
\hline Chicago Fed National Activity Index & & & & & & & $\begin{array}{r}-0.31 \\
(-106)\end{array}$ & -0.26 \\
\hline$R^{2}(\%)$ & 1.95 & 3.55 & 2.03 & 3.60 & 2.02 & 3.58 & $\begin{array}{r}(-. .0) \\
3.82\end{array}$ & 4.88 \\
\hline
\end{tabular}


Table 10: Predictability of stock returns by stock market interest

The predictability of monthly excess returns on the Center for Research in Security Prices value-weighted stock portfolio over the one-month T-bill rate is tested. All predictor variables are lagged one month. The table reports standardized coefficients with heteroskedasticity-consistent $t$-statistics in parentheses. The sample period is 1984:1-2008:12.

\begin{tabular}{|c|c|c|c|c|c|c|c|c|}
\hline Predictor variable & (1) & $(2)$ & $(3)$ & (4) & $(5)$ & (6) & (7) & (8) \\
\hline \multirow[t]{2}{*}{ Short rate } & -0.55 & -0.73 & -0.62 & -0.73 & -0.30 & -0.49 & -0.98 & -1.06 \\
\hline & $(-0.86)$ & $(-1.14)$ & $(-1.00)$ & $(-1.12)$ & $(-0.47)$ & $(-0.75)$ & $(-1.69)$ & $(-1.76)$ \\
\hline \multirow[t]{2}{*}{ Yield spread } & -0.53 & -0.59 & -0.47 & -0.57 & -0.31 & -0.34 & -0.74 & -0.76 \\
\hline & $(-1.28)$ & $(-1.42)$ & $(-1.09)$ & $(-1.22)$ & $(-0.75)$ & $(-0.83)$ & $(-1.83)$ & $(-1.86)$ \\
\hline \multirow[t]{2}{*}{ Dividend yield } & 0.77 & 0.81 & 0.82 & 0.82 & 0.48 & 0.46 & 1.02 & 1.02 \\
\hline & $(1.36)$ & $(1.44)$ & $(1.47)$ & $(1.46)$ & $(0.83)$ & $(0.80)$ & $(1.88)$ & $(1.88)$ \\
\hline \multirow[t]{2}{*}{ Stock market interest } & & 0.38 & & 0.33 & & 0.50 & & 0.24 \\
\hline & & $(1.38)$ & & $(0.88)$ & & $(1.76)$ & & $(0.90)$ \\
\hline \multirow[t]{2}{*}{ Stock returns } & & & 0.29 & 0.08 & & & & \\
\hline & & & $(0.83)$ & $(0.16)$ & & & & \\
\hline \multirow[t]{2}{*}{ Stock market imbalance } & & & & & -0.45 & -0.56 & & \\
\hline & & & & & $(-1.80)$ & $(-2.12)$ & & \\
\hline \multirow[t]{2}{*}{ Chicago Fed National Activity Index } & & & & & & & 0.70 & 0.65 \\
\hline & & & & & & & $(1.97)$ & $(1.84)$ \\
\hline$R^{2}(\%)$ & 1.05 & 1.68 & 1.40 & 1.69 & 1.92 & 2.97 & 3.22 & 3.45 \\
\hline
\end{tabular}




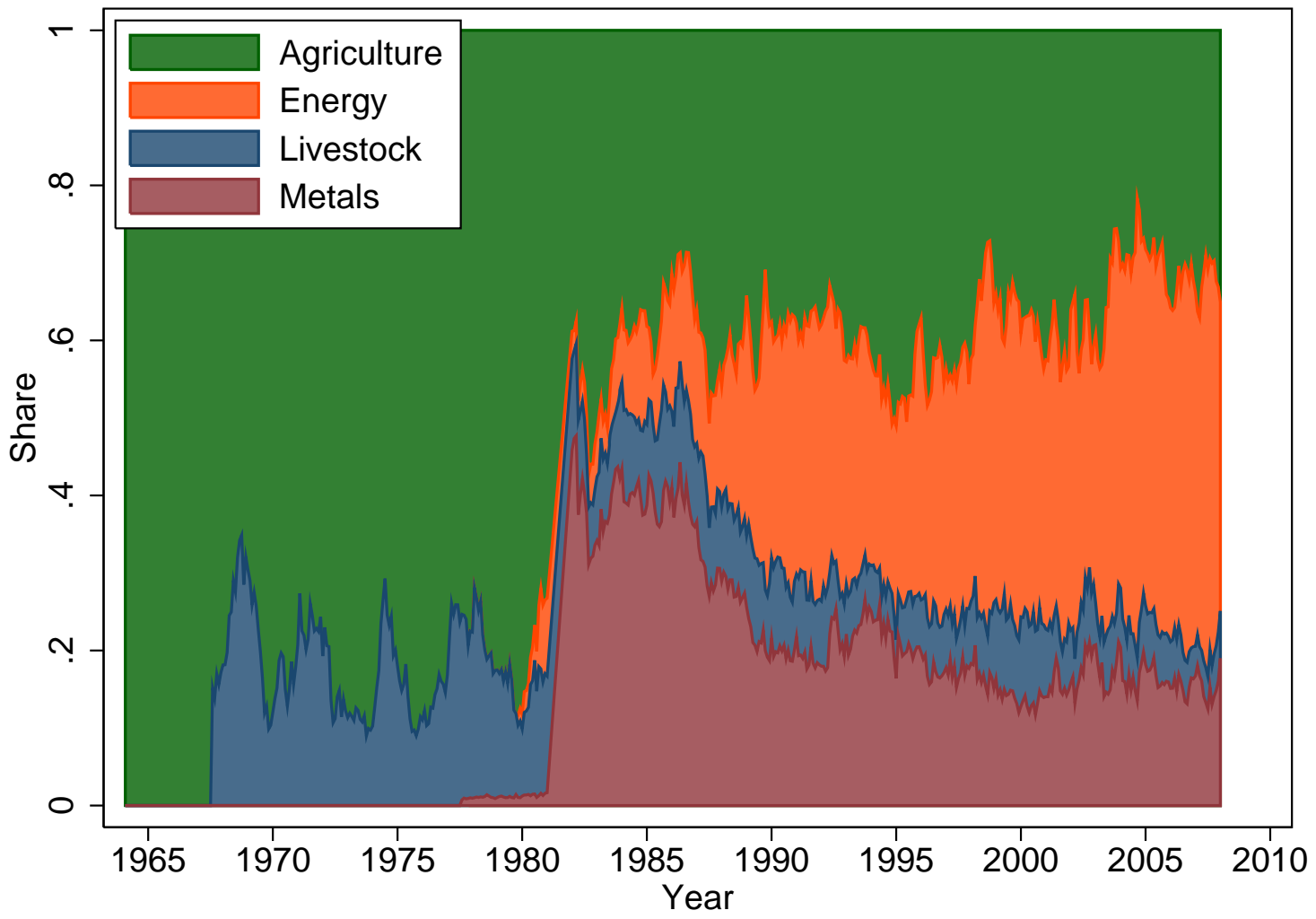

Figure 1: Open interest in commodity futures by sector The share of dollar open interest in commodity futures that each sector represents is shown. The sample period is 1965:1-2008:12. 
Commodity market

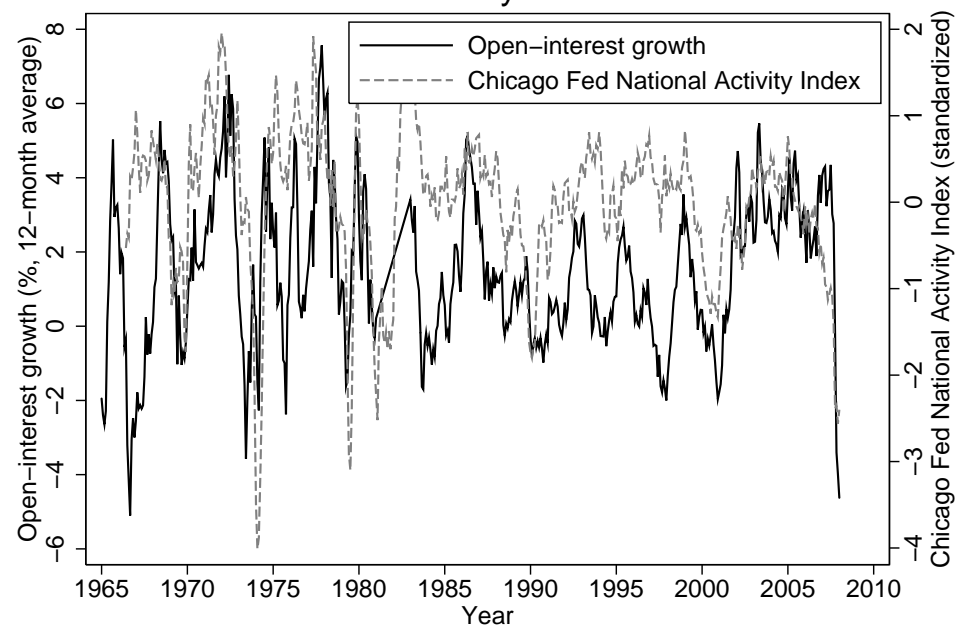

Bond market

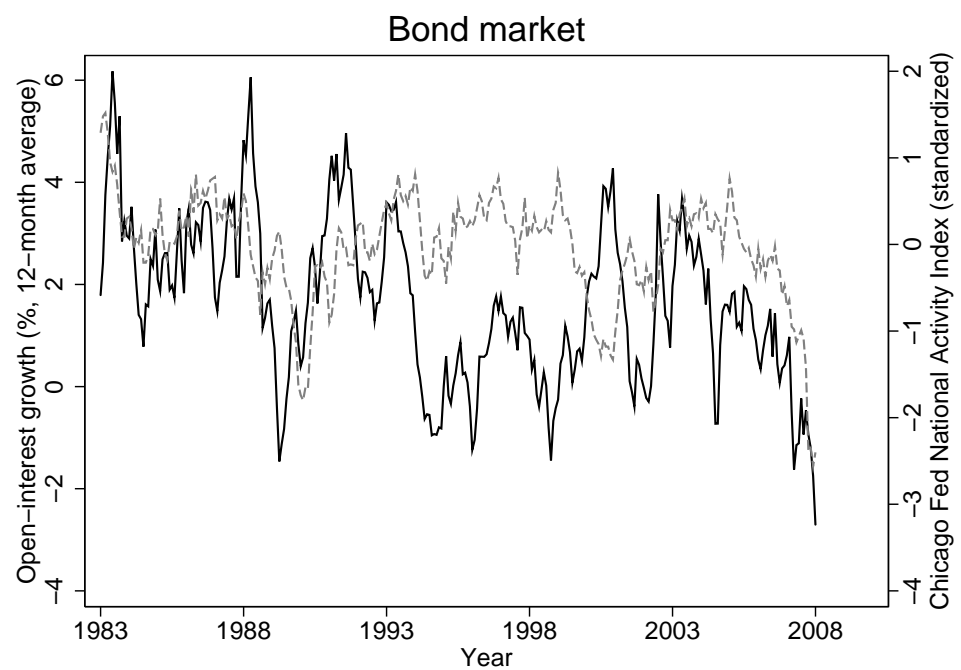

Currency market
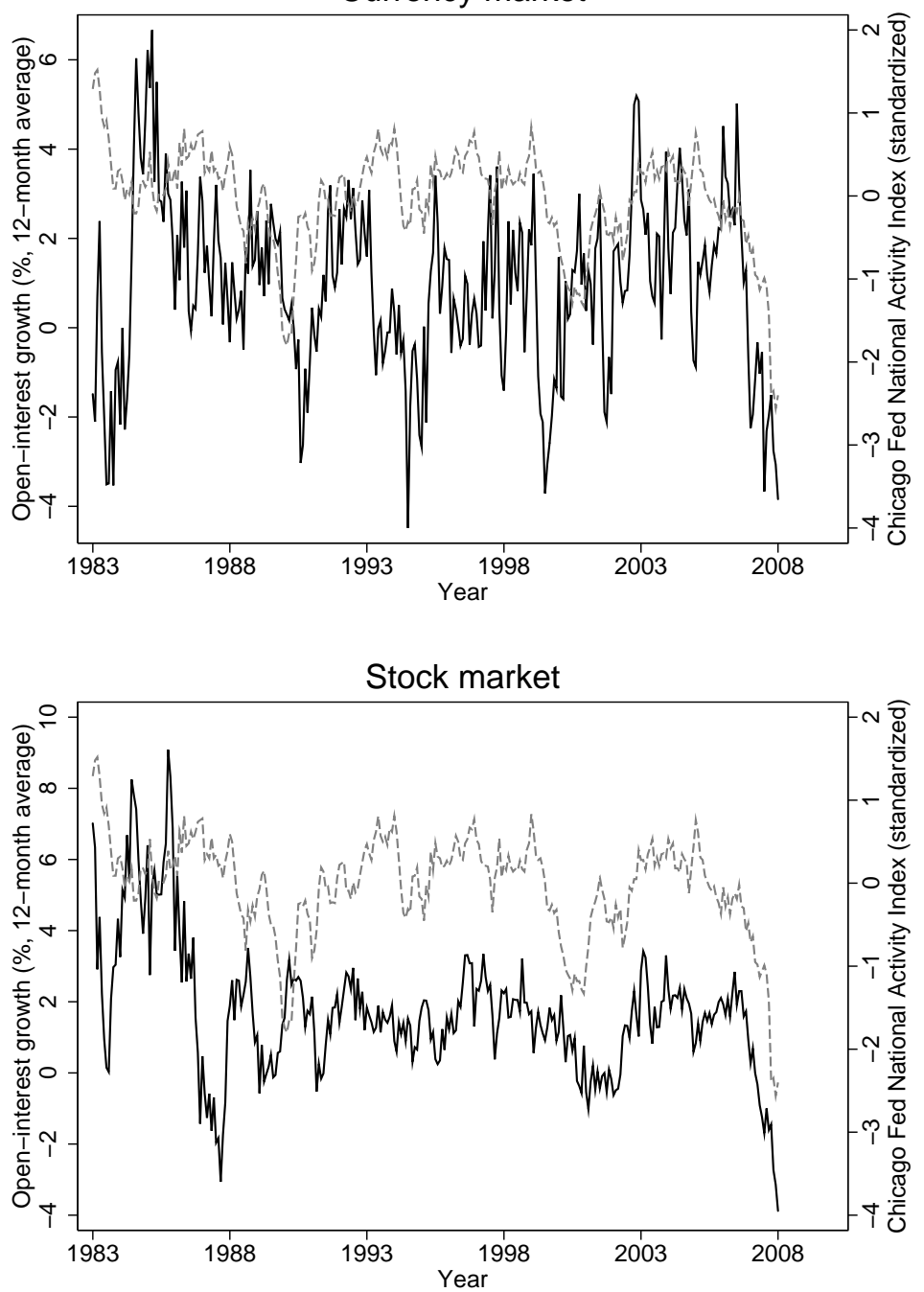

Figure 2: Growth rate of open interest and the Chicago Fed National Activity Index

The 12-month geometrically averaged growth rate of commodity, currency, bond, and stock market interest is shown. Also the Chicago Fed National Activity Index, which is a weighted average of 85 monthly indicators of US economic activity, is shown. The sample period is 1965:12-2008:12 for the commodity market and 1983:12-2008:12 for the other markets. 

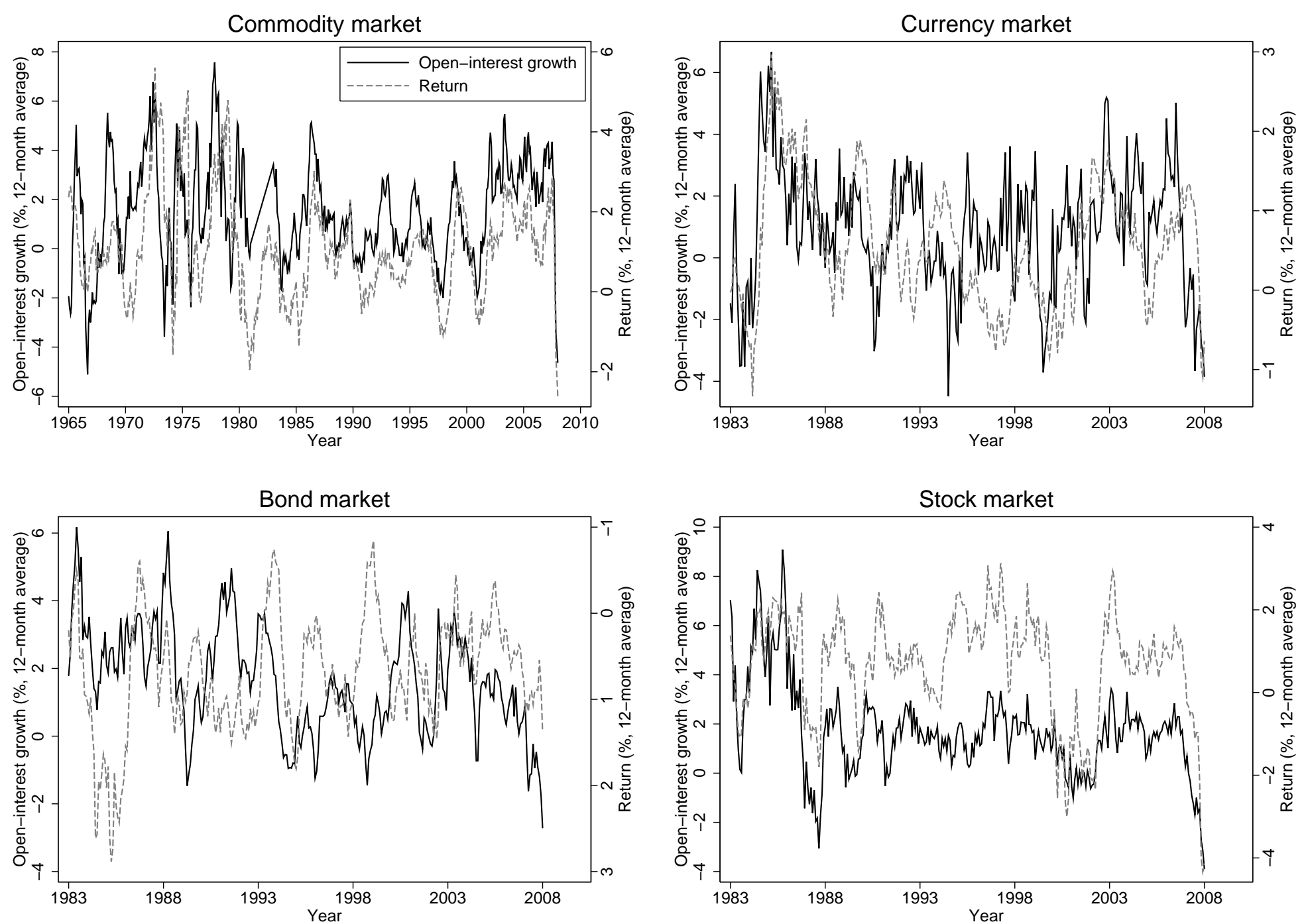

Figure 3: Growth rate of open interest and returns

The 12-month geometrically averaged growth rate of commodity, currency, bond, and stock market interest is shown. Also the 12-month geometrically averaged returns on a portfolio of fully collateralized commodity futures, a portfolio of fully collateralized currency futures, the 10-year US Treasury note, and the Center for Research in Security Prices value-weighted stock portfolio are shown. The sample period is 1965:12-2008:12 for the commodity market and 1983:12-2008:12 for the other markets. 